\title{
FLYING SERPENTS?
}

\section{By D. J. WISEMAN}

The expression ment. In both instances in Isaiah the current interpretation, which implies the existence of semi-mythological creatures, is open to question. ${ }^{1}$ In Isaiah $14: 29$ the 'fiery flying serpent' (AV; 'flying serpent', NEB) is part of a description of punishment to come upon the Philistines. The 'flying serpent' is said to be the offspring of a viper ( only here, is not an unusual species of snake. ${ }^{2}$ In Isaiah $30: 6$

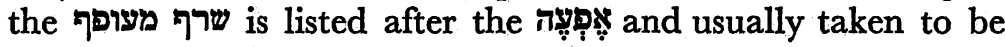
the sand-viper ( $c f$. Is. $59: 5 ; \mathrm{Jb} .20: 16)$. Since the sand-viper, the lion and the lioness which inhabited the Negeb are cited as a common danger to passing donkey and camel caravans coming from Egypt, it is surprising to find an otherwise unknown species of 'venomous flying serpent' (NEB) associated with them. ${ }^{3}$

The generally accepted interpretation of 'flying snake' appears to rest almost wholly on the winged serpents of Arabia described by Herodotus (iii, 107): 'The trees which bear the frankincense are guarded by winged serpents, small in size and of varied colours, whereof vast numbers hang about every tree. They are of the same kind as the serpents which invade Egypt and there is nothing but the smoke of styrax which will drive them from the trees.'4

Herodotus, however, expressly notes that, contrary to other snakes which are harmless, these lay eggs and hatch a vast

1 This subject was first taken up as part of a paper read to the Old Testament Study Group of the Tyndale Fellowship at Cambridge in July 1969 .

2 Only here, usually 'צוצ' (Is. I I:8; 59:5 and Pr. 23:32 where it is synonymous with wis). It may be the 'adder'.

${ }^{8}$ There is no warrant for taking these creatures just as a figure of speech, as we might when speaking of someone as a dragon, or as demonic beings in the form of winged serpents ( $c f$. M. Noth, Überlieferungsgeschichte des Pentateuch, Kohlhammer, Stuttgart (1960), 134).

4 Rawlinson, p. 262. Ammianus Marcellinus xxii, 5 probably follows Herodotus in writing of flying serpents from the Arabian marshes which produced a deadly poison. 
number of young. 'These winged serpents are nowhere to be seen except in Arabia where they all congregate together. This makes them appear so numerous' (iii, rog). He had earlier told how in the spring the winged snakes come flying from Arabia towards Egypt but are met in the gorge (near Buto) by the birds called ibis who foil their entrance and destroy them all' (ii, 75).

It is uncertain whether these winged creatures are to be identified as snakes. Though there are occasional reports of terrestrial snakes which abnormally leap through the air in a series of jumps from the ground, these cannot rightly be described as 'flying snakes'. ${ }^{5}$ It is possible that Herodotus is depicting a species of dragonfly ${ }^{6}$ or tree-lizard. ${ }^{7}$ The latter are certainly the 'reptiles, two cubits long with membraneous wings like bats' described by Strabo in India (I5.1.37). Strabo elsewhere mentions the waterless sandy region round the Bitter Lakes which contain many reptiles, but the wings they are supposed to have are mere travellers' tales and the serpents lie hidden burrowing in the sand (I 7.1.21). Theophrastus, in discussing the myth of the cinnamon tree (that of Herodotus iii, 107), says that it 'grows in ravines where it is guarded by poisonous serpents, against which the gatherer has to protect both hands and feet'. ${ }^{8}$

There is no representation of flying snakes among the fauna of Egypt ${ }^{9}$ or Mesopotamia ${ }^{10}$ and it is suggested that in view of the doubtful identification of these 'flying snakes' some other explanation be sought. Either they were some poisonous winged

5 Dr Maurice Burton (formerly of the British Museum, Natural History) in a letter to me dated 16 May 1967 . The so-called 'flying snakes' of S.E. Asia can be ruled out because of the geographical location.

6 The dragonfly is known in ancient Mesopotamia (Alkad. kulilu).

7 C. Sourdille, La durée et l'étendue du voyage d'Hérodote en Egypte, E. Leroux, Paris (1910), 74-5. ${ }^{8}$ Hist. Plant., ix. 6. I owe this reference to Mrs A. Kuhrt.

${ }^{9} \mathrm{I}$ am indebted to $\mathrm{Mr} \mathbf{K}$. A. Kitchen for the following note. In Egypt, winged snakes occur only in 'heraldic' decoration, extending their wings to protect the figure or name of the king (e.g. B. Bruyère, Mertseger, L'Institut français d'archéologie orientale, Cairo (1930), 256, fig. 127), or in the highly mythological 'guide-books' to the Netherworld in the Tombs of the Kings, where their fanning wings serve to produce life-breath (e.g. E. Hornung, Das Amduat, II, Harrassowitz, Wiesbaden (1963), 84, No. 285, to I, Beilage, Vierte Stunde, 285), but not for flight.

${ }_{10}$ It is significant that though snakes appear frequently in the glyptic art none are winged, even when associated with winged goddesses, dragons (lion type), bulls, horses, lions and hybrid creatures (so H. H. Frankfort, Cylinder Seals, Macmillan, London (1939), 1 r gff.). 
insect (צוֹף) or the ascription 'flying' (מצופף) may be questioned. ${ }^{11}$

The Akkadian appu, 'tip, spur' is used of a staff or of parts of the body, ${ }^{12}$ while uppu has a more specific meaning of a tip of metal on implements and as such has been translated 'prick, goad'.18 In an unpublished lexical text it is the ox-herd/ driver's metal studded stick. 14 Such a rod or stick was tipped with protruding nails. ${ }^{15}$ That an uppu was used for pricking or jabbing is clear also from a bilingual Sumero-Akkadian proverb or truism which observes that no-one moves an ox forward by striking it in the face with a goad. ${ }^{16}$ The metal tipped rod could be used for drumming ${ }^{17}$ and was an obviously lethal weapon in Shamgar's hand (Jdg. $3: 31$ ); $;^{18}$ uppu might be generally used of a stick. ${ }^{19}$

Is it possible that מעופר may simply denote 'jab, prick'20 and that Isaiah's 'fiery flying serpents' are but 'deadly poisonous snakes' in general? If this should prove so then Ezekiel 32:10, 'when I brandished my sword before them' would be better translated, 'when I jab my sword at them'. And could the figurative 'eyelids of the dawn' (רסיdescription of the first shafts of sunlight ?21

11 The po'el ptcp occurs only in Isaiah and in Ezk. 32:10, see below.

12 $C A D$ A/ii, 196-8, possibly to be distinguished from appu 'nose'; $c f$. compounds with $a p p$ - to denote urgency or emphasis.

${ }^{14} \mathrm{Hh}$ xiii. Io bulug šà gud. ra. zabar: $u p-p u$.

${ }^{15}$ So the zuqaqizpu 'scorpion' is used of the metal barbs on a scourge or goad (MSL VII, I54, so I Ki. 12:1 I, 14).

${ }_{16}$ W. G. Lambert, Babylonian Wisdom Literature, Clarendon Press, Oxford (1960), 242 (iii, 19-20), 248-9. I would translate this 'Do you strike the face of a moving ox with a goad?' Lambert translates uppu as 'strap' on the basis of a supposed meaning of 'handle, thong' for its part in a door lock (A. Salonen, Die Türen des alten Mesopotamien, Finnish Academy of Sciences, Helsinki (I96I), 90, I4I). It is, however, more likely that the uppu was the protusion of notches or nails which formed the 'key' to ancient locks ( $c f$. S. Smith, $R A$ 21 (1924), 80).

${ }^{17}$ MSL VII, I53, line 190, where uppu is parallel to lilissu, 'a drum' (cf. Atrahasis i. 214). It might also be used of a hollow tube used in chemical operations: R. Campbell Thompson, Dictionary of Assyrian Chemistry and Geology, Clarendon Press, Oxford (1936), 118. This could be important if a Heb. * $p p$ should stand for the hollow fang of a snake through which the poison is ejected.

18 Here the euphemism מלמד הבראר is used for the goad (in Heb. only דרב, I Sa. 13:21) which implies metal sharp enough to prod or press a recalcitrant animal. It was composed of sharp nails (Ec. I2:1 I).

19 So my suggestion in Bulletin of the School of Oriental and African Studies 30 (1967), 501. Prof. W. G. Lambert has suggested to me that BM. 82684, iii, I3' might be read ar- $h u$, 'half-brick' rather than $u p$-pu, 'stick'. Collation shows that the reading $a r-h i$ is possible though this is only attested otherwise in Old Babylonian and there is no evidence that 'tin' was transported in this form. Uppu as a star formation ( $Z A 43$, n. F. 9 (1936), 238, 104) is of little help in identification (here it is usually equated with andug $d$ which is taken to be a loan-word from Sum. *an.du(n).gu 'cloud'.).

so This may be a semantic extension of 7 y rather than * The Akkadian hapax leg. *apäpum $A R M$ IV 43 r. 7 is related to Heb. 'pp 'go round' in A.Hw.B., 57 (cf. $C A D \mathrm{~A} / \mathrm{ii}$ 166, mng.uncert.).

g1 Similarly I have suggested that baräritu 'the evening watch' is derived from the sunset, baräru meaning both 'to glow red' and 'to flash out' (BSOAS 30 (1967), 502, n. $5^{8}$ ). 